\title{
Coagulopathy in COVID-19 Patients and Endovascular Treatment, Reports of 4 Patients
}

\author{
Mohammadreza Babaei $^{1}$ (D), Mohammad-Ali Mohammadi-Vajari²*(D), \\ Erfan Mohammadi-Vajari ${ }^{3}$ iD
}

1. Assistant Professor of Radiology, Fellowship of Interventional Radiology, Department of Radiology, Firouzgar Hospital, Iran University of Medical Sciences, Tehran, Iran

2. Radiology Resident, Department of Radiology, Firouzgar Hospital, Iran University of Medical Sciences, Tehran, Iran

3. Medical Student, School of Medicine, Guilan University of Medical Sciences, Rasht, Iran

\section{ABSTRACT}

Due to the respiratory infection of SARS-CoV-2, COVID-19 pandemic has now become a global threat. The thrombotic complications are common in COVID-19 patients which have been extensively addressed in various studies. The hemorrhagic complications, however, have received less attention. In this article, 4 cases of COVID-19 patients with hemorrhagic complications are presented.

All 4 patients were hospitalized in ICU and received routine COVID-19 treatments such as heparin prophylaxis. During hospitalization, all four patients had rectus sheath hematoma and retroperitoneal hemorrhage. For controlling which, they underwent embolization.

Embolization of the inferior epigastric artery and the anterior trunk of internal iliac artery was carried out under fluoroscopyguided angiography. The active hemorrhage of the patients was controlled. Three patients recovered after the treatment and were discharged while one patient, unfortunately, died due to the severity of the pulmonary involvement, old age, and hemorrhage.

First, the hemorrhage of these patients was considered to be the result of the hemorrhagic complications due to the use of heparin. But the hemorrhage volume was not justifiable with the symptoms and complications of prophylaxis dosage of heparin. The attention was gradually drawn to the coagulopathy of the COVID-19 patients. Further investigations are required to clarify the role of effective factors and complications of coagulopathy in patients with COVID-19 and their appropriate treatment.

Keywords: Blood coagulation disorders, COVID-19, SARS-CoV-2, Radiology, Interventional

Received: 2021/01/03; Accepted: 2021/03/20; Published Online: 2021/04/14

Corresponding Information: Mohammad-Ali Mohammadi-Vajari, MD, Radiology Resident, Department of Radiology, Firouzgar Hospital, Iran University of Medical Sciences (IUMS), Tehran, Iran. Email: malimv71@yahoo.com

Copyright (C) 2021, This is an original open-access article distributed under the terms of the Creative Commons Attribution-noncommercial 4.0 International License which
permits copy and redistribution of the material just in noncommercial usages with proper citation.

Use your device to scan and read the article online

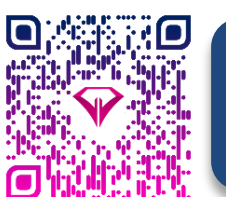

Babaei M R, Mohammadi-Vajari M, Mohammadi-Vajari E. Coagulopathy in CoVID-19 Patients and Endovascular Treatment, Reports of 4 Patients. Iran J Med Microbiol. 2021; 15 (2) :257-265

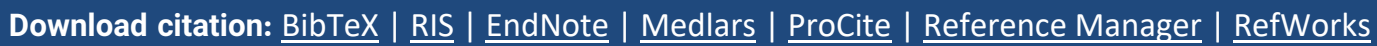

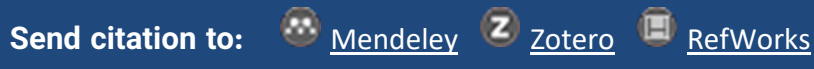

\section{Introduction}

Due to the respiratory infection of SARS-CoV-2, COVID-19 pandemic has now become a global threat (1-4). Numerous papers have addressed the pulmonary symptoms of this disease which highly contributed to the identification of the pathogenesis of COVID-19 infection. It seems that ACE2 receptors are involved in the entrance of the virus into the cells. Regarding the presence of these receptors on the surface of the alveoli epithelial cells and vascular endothelium, these cells and organs are prone to this 
virus (5). The incidence of thrombotic complications such as Pulmonary Thromboembolism, deep vein thrombosis, ischemic stroke, cardiac infarction, and arterial embolism is high in COVID-19 patients which has been reported in numerous studies before $(6,7)$. The initial clinical sign of coagulopathy in COVID-19 is organ failure while hemorrhagic complications are less common. The changes in the hemostatic markers such as D-dimer and fibrin and fibrinogen products have indicated that the basis of the coagulopathy is probably the fibrin products (8). However, the hemorrhagic complications of COVID-19 patients have received less attention. In this context, the current study presents four COVID-19 patients with hemorrhagic complications and describes their treatments.

\section{Case Presentation}

This paper investigates four COVID-19 patients with hemorrhagic complications (female; with a mean age of 48). All four patients had positive PCR tests for COVID19 and exhibited bilateral pulmonary involvement with typical COVID-19 pattern (CORADS=6).

These patients were admitted in the ICU and received routine COVID-19 treatments. None of them received mechanical ventilation or intubation and they were treated under the guideline of the hospital in the ICU. Regarding the risk of thrombotic events, all four patients received a prophylactic dose of heparin.

During hospitalization, all four cases had rectus sheath hematoma and retroperitoneal hemorrhage. The first patient was about to recover and changed from CBR (Complete Bed Rest) to RBR (Relative Bed Rest) condition. Following the physical activities, the patient fell and fainted. Regarding the declined consciousness and faint, she was investigated. She had abdominal and pelvic ultrasonography due to the bruising in the anterior parts of the abdomen. Further investigations showed rectus sheath hematoma and accumulation of loculated fluid in the retroperitoneum (Figure 1). In these patients, due to hemorrhage in the rectus sheath and retroperitoneum, surgical treatment was not the choice and endovascular treatment was selected. Therefore, to control the hemorrhage, the patients underwent a less invasive intervention (arterial embolization) according to the volume of the hemorrhage and their conditions. Subsequently, three other patients with the same symptoms but in CBR status, experienced symptoms of volume reduction and shock. Further investigations indicated declined hemoglobin followed by hemorrhage in the rectus sheath and retroperitoneum who also received arterial embolization.

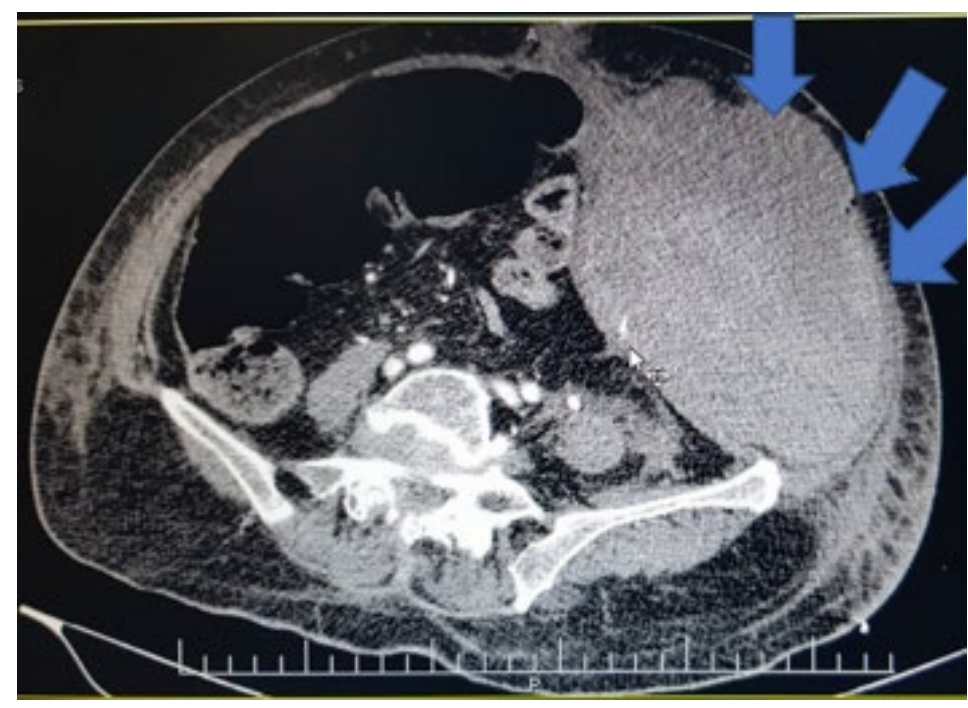

Figure 1. Massive rectus sheath hematoma in contrast enhanced abdominopelvic CT

Inferior epigastric artery and anterior trunk of internal iliac artery embolization was performed under fluoroscopic and angiographic guidance (Figure 2 and 3). Active bleeding of patients was controlled. Three patients were discharged from the hospital after completing the appropriate course of treatment. One patient, unfortunately, died due to the severity of pulmonary involvement caused by COVID- 19 due to her advanced age and volume of hemorrhage. 


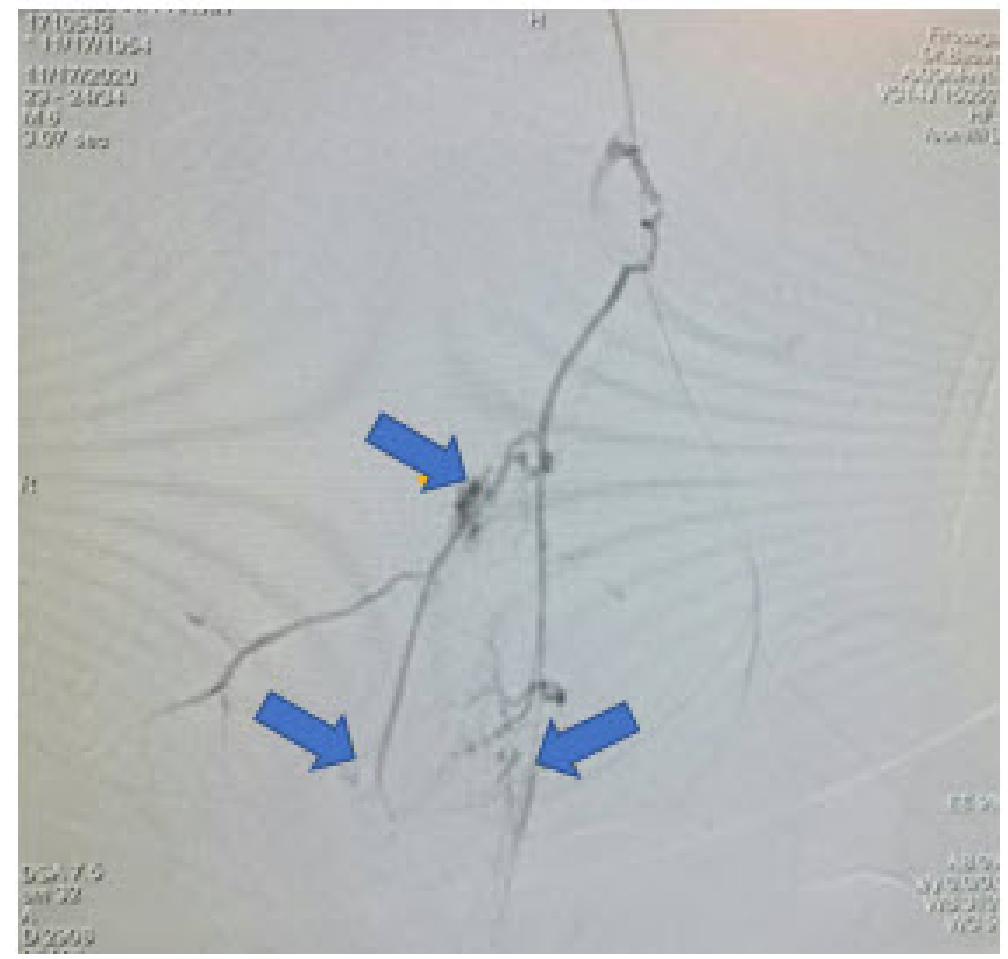

Figure 2. DSA Angiography of pelvic arterial system, multiple foci of bleeding in pelvic floor representing as extravasation in Internal Iliac Artery Territory

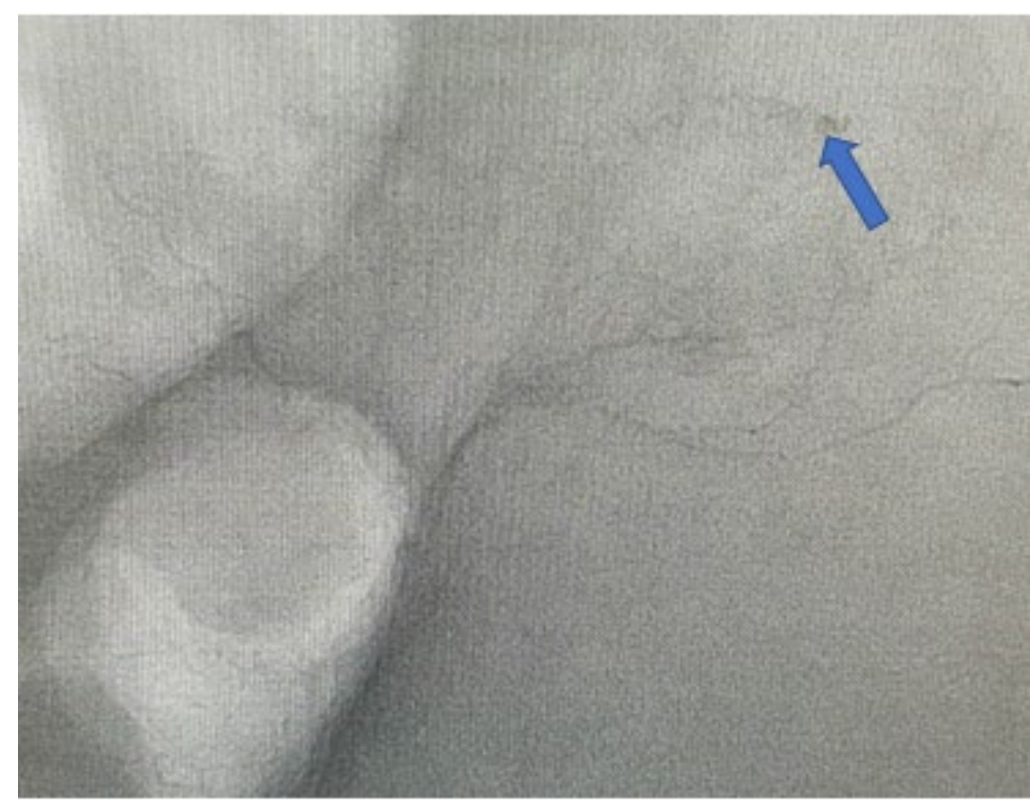

Figure 3. Selective Angiography, arterial blush in the territory of inferior epigastric artery shows the bleeding site

\section{Discussion}

Coagulation-anticoagulant imbalance during the immune response to the virus leads to overproduction of inflammatory cytokines and multi-organ failure. Initially, since all four patients were treated with a prophylactic dose of heparin, their hemorrhage was attributed to heparin-induced hemorrhagic complications. Due to falling of the first patient, it was also suggested as a cause of hemorrhage in the patient. However, the volume of bleeding and the symptoms caused by volume loss was not justifiable with the side effects of the prophylactic dose of heparin in the literature review $(9,10)$. The other three patients also had a hemorrhage in the CBR state, which also further declined the chance of falling as the underlying cause of 
hemorrhage. Gradually attention was paid to the incidence of coagulopathy in COVID-19 patients. The occurrence of these symptoms and hemorrhage in patients can be justified in the setting of coagulopathy in COVID-19 patients. The retrograde evaluation of the first patient indicated a gradual decrease in hemoglobin level, which also suggests that the patient's falling could also be due to the decrease in hemoglobin level. Although venous thromboembolism and arterial thrombosis are more common in COVID-19 coagulopathy, in some cases, the clinical symptoms overlap with hemophagocytic syndromes, antiphospholipid, and thrombotic microangiopathies (11). The use of heparin prophylaxis is still controversial in COVID-19 patients. Cerebral hemorrhage has also been reported in COVID- 19 patients, some of which have been secondary to prophylactic use of heparin. Several guidelines have been developed and employed for the treatment and management of coagulopathy and thrombotic complications in COVID-19 patients (12). Numerous studies have addressed the mechanism and pathogenesis of thrombotic and hemorrhagic complications of COVID-19; however, further investigations are required to clarify the role of effective factors and complications of coagulopathy in patients with COVID-19 and their appropriate treatment (12, 13). It may also be possible to prevent hemorrhagic and thrombotic complications in patients by evaluating coagulation tests during hospitalization and before discharge, which also requires further investigations.

\section{Conclusion}

There is increasing awareness of coagulation disorders in Covid-19 infection. Thrombotic complications seem to be common among this patient population, which may necessitate preparing appropriate guidelines for its management. However hemorrhagic complications and their proper treatment should also be taken into consideration in covid-19 infection.

\section{Acknowledgment}

Hereby I would like to thank and appreciate Iran University of Medical Sciences for cooperation in the stages of the project.

\section{Funding}

This research did not receive any specific grant.

\section{Conflict of Interest}

Authors declared no conflict of interests.

\section{Ethical Statement}

All ethical standards are met in this study.

\section{Patient's Consent}

A written consent was obtained from the patient. 


\title{
كواكولوياتى در بيماران مبتلا كوويد 19 و درمان اندوواسكولار، كزارش † مورد
}

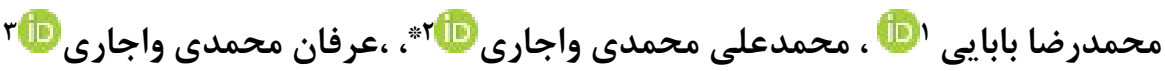

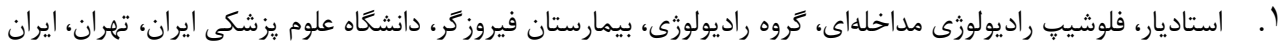

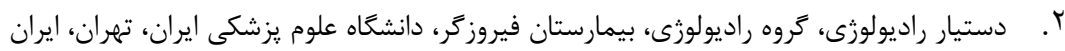

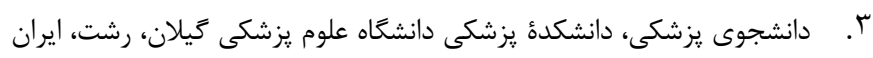

\section{جكيله}

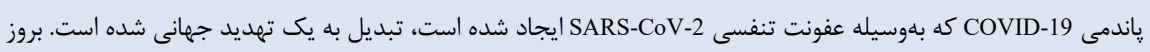

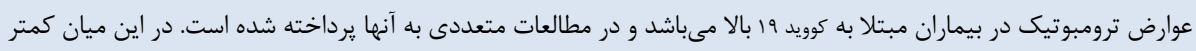

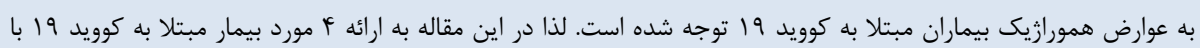
عوارض همورزايك يرداخته شده است.

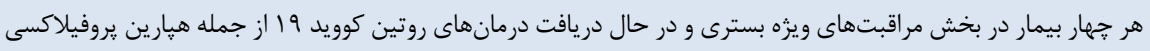

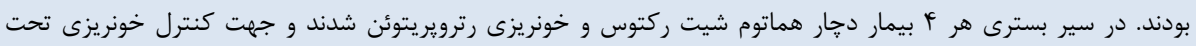
آمبوليزاسيون قرار ترفتند.

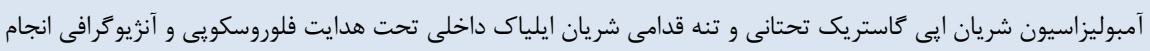

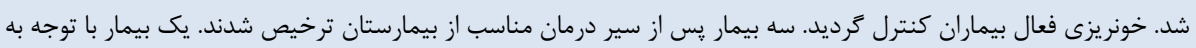

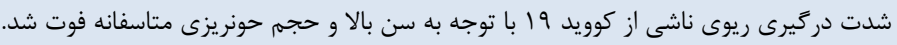

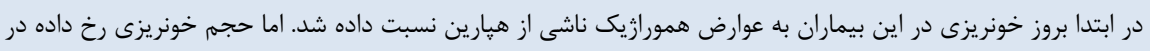

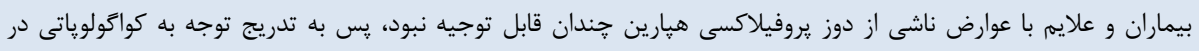

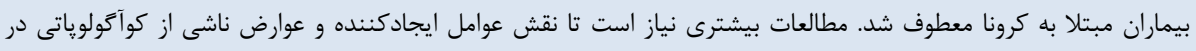

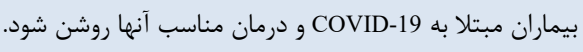

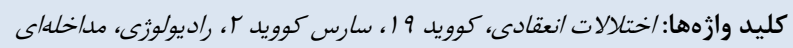

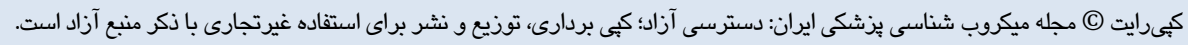

اطلاعات مقاله

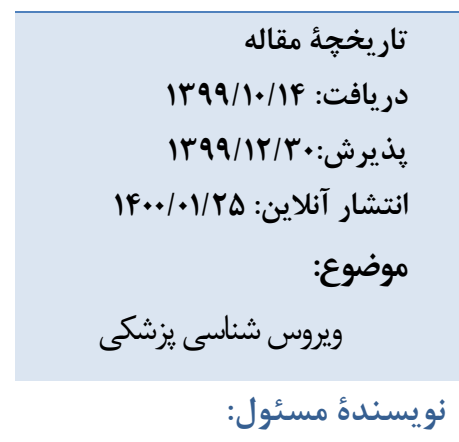

محمد على محدى واجارى، دستيار

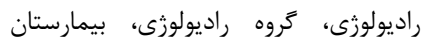
فيروز ايران ايميل: malimv71@yahoo.com

مقلمهه

شايع هستند. تغييرات ماركرهاى هموستاتيك در بررسىهاى

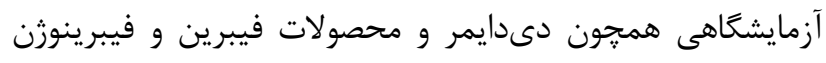

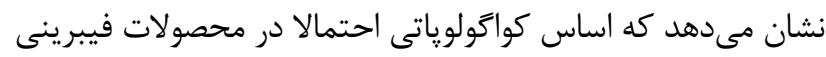

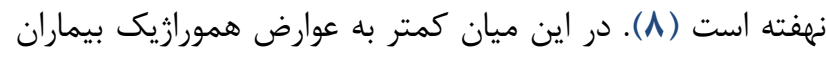

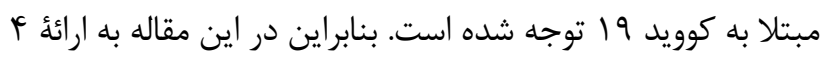

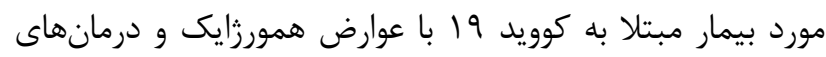
انجام شده در اين موارد يرداختهايم.

\section{كَزارش موارد}

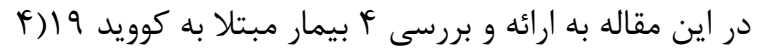

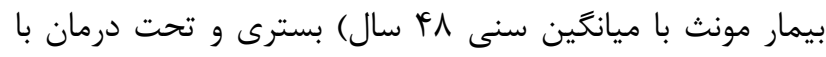

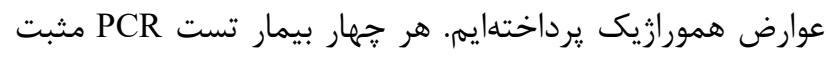

SARS-CoV- پاندمى كوويد 19 كه به وسيله عفونت تنفسى إندي

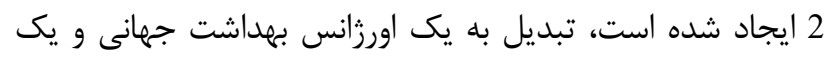
دغدغه جهانى شده است (1-1). مقالات متعددى در رابطه با بال

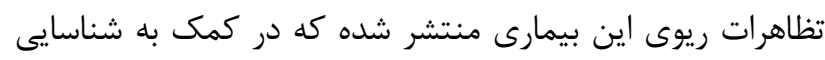

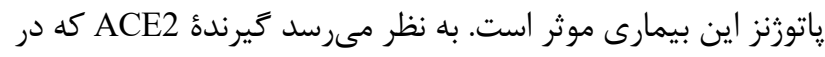

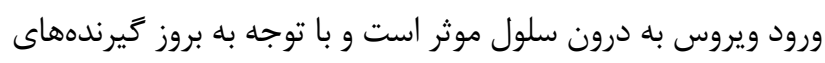

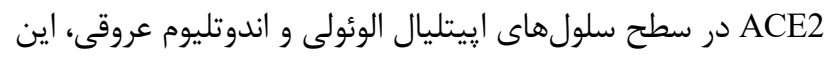

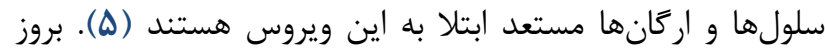

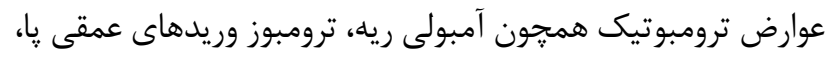

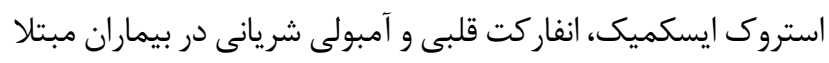

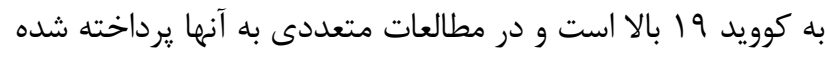

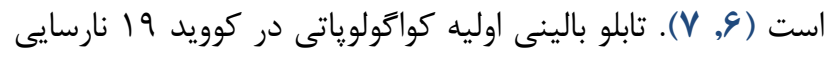
اركانها است، درحالى كه عوارض همورازيك و خونريزى الهنده كمتر 
شد. با توجه به يك نوبت كاهش هوشيارى faint falling down

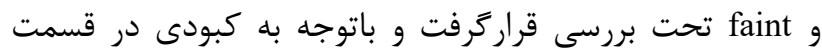
قدامى شكم تحت سونوگرافى شكم و لخن و نسج نرم زيرجلدى برى ناحيه قدامى شكم قرار گرفت. در طى اين بررسى ها متوجه هماتوم شيت ركتوس و تجمع مايع لكوله در رترويريتوئن شدند (شكل ( ).

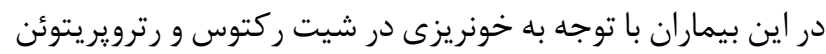
درمان جراحى انتخابى نبوده و روش انتخابى درمان اندووسكولار مىباشد. لذا براى كنترل خونريزى با توجه به حجم خونريزى و شرايط بيمار تحت آمبوليزاسيون شريانى به عنوان اقدام كمتر

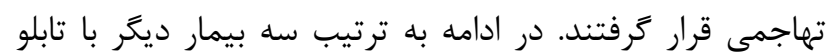
مشابه اما در وضعيت CBR دجار علايم كاهش حجم و شوك شدند و در بررسىهاى تكميلىتر افت همو گلوبين و سيس خونريزى در شيت ركتوس و رترويريتوئن گَزارش و براى آنها نيز آمبوليزاسيون شريانى انجام شد.
كوويد 9 او درگيرى ريوى دوطرفه با نماى تيبيك كوويد 19 را داشتند (CORADS=6).

اين بيماران در بخش مراقبتهاى ويثه بسترى و در حال دريافت درمانهاى روتين كوويد 9 إبودند. هيج يك از بيماران تحت ونتيلاسيون مكانيكى و يا انتوبه نبودند و با توجه به كرايتريا و كايدلاين بيمارستان در بخش مراقبت هاى ويزه تحت درمان قرار

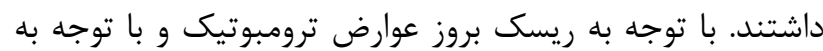

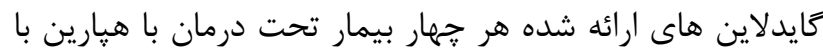
دوز يروفيلاكسى قرار داشتند. در سير بسترى هر f ب بيمار دجار هماتوم شيت ركتوس و خونريزى رترويريتوئن شدند.اولين بيمار در سير بسترى خود در حال بهبود علايم بود و از وضعيت CBR به RBR تغيير فعاليت

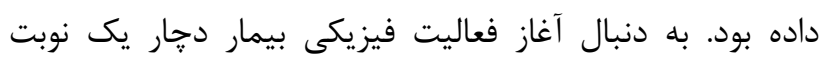

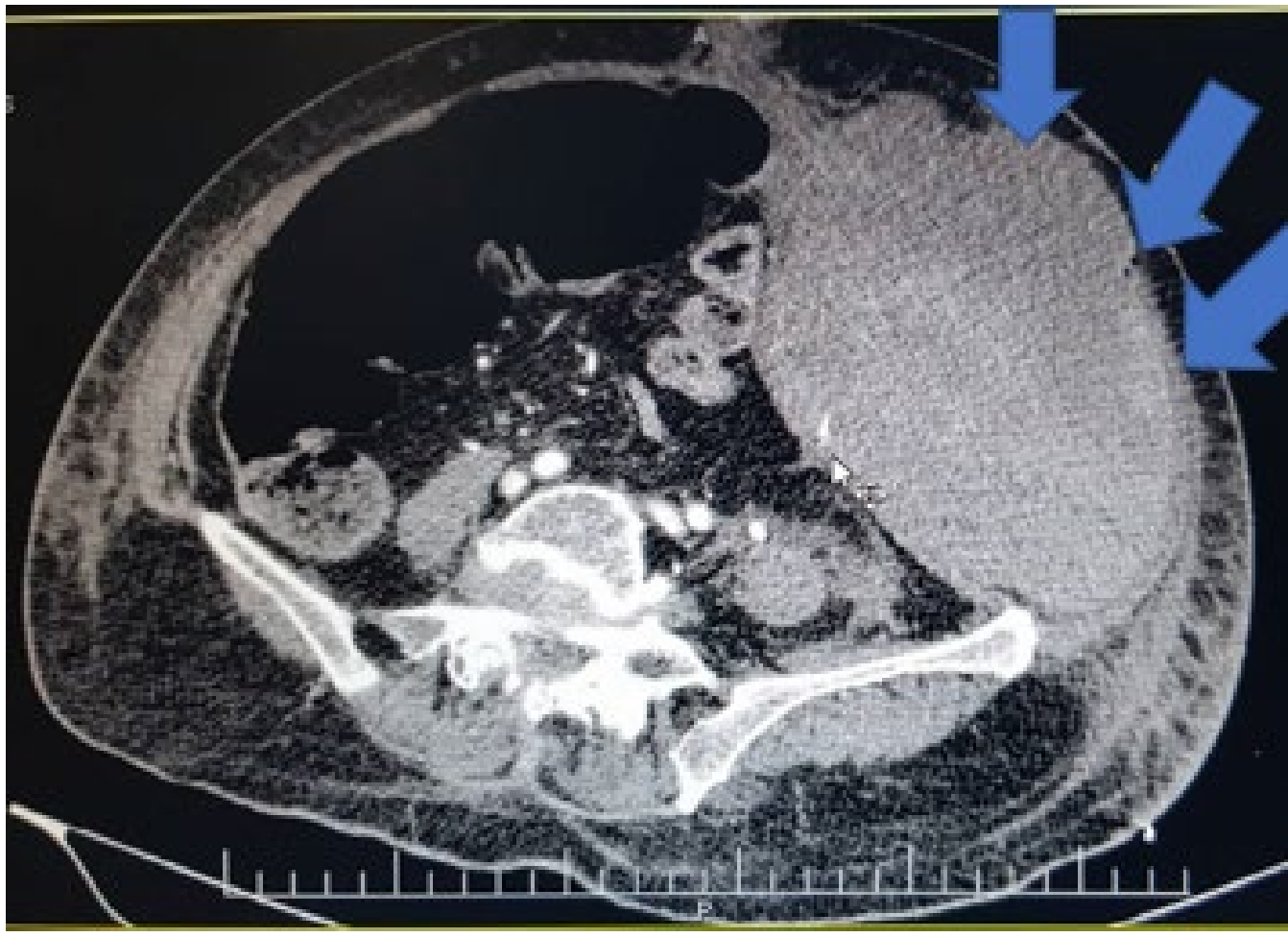

شكل ا. هماتوم وسيع شيت ركتوس در سى تى با تزريق شكم و لَّن

كرديد. سه بيمار هس از تكميل سير درمان مناسب از بيمارستان ترخيص شدند. يك بيمار با توجه به شدت درگيرى ريوى ناشى از

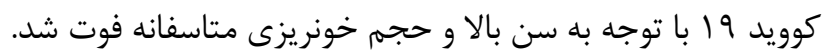

آمبوليزاسيون شريان ايى كاستريك تحتانى و تنه قدامى

شريان ايلياك داخلى تحت هدايت فلوروسكويى و آنزيوگر افى جهت بيماران انجام شد. (شكلهاى ؟، س) خونريزى فعال بيماران كنترل 


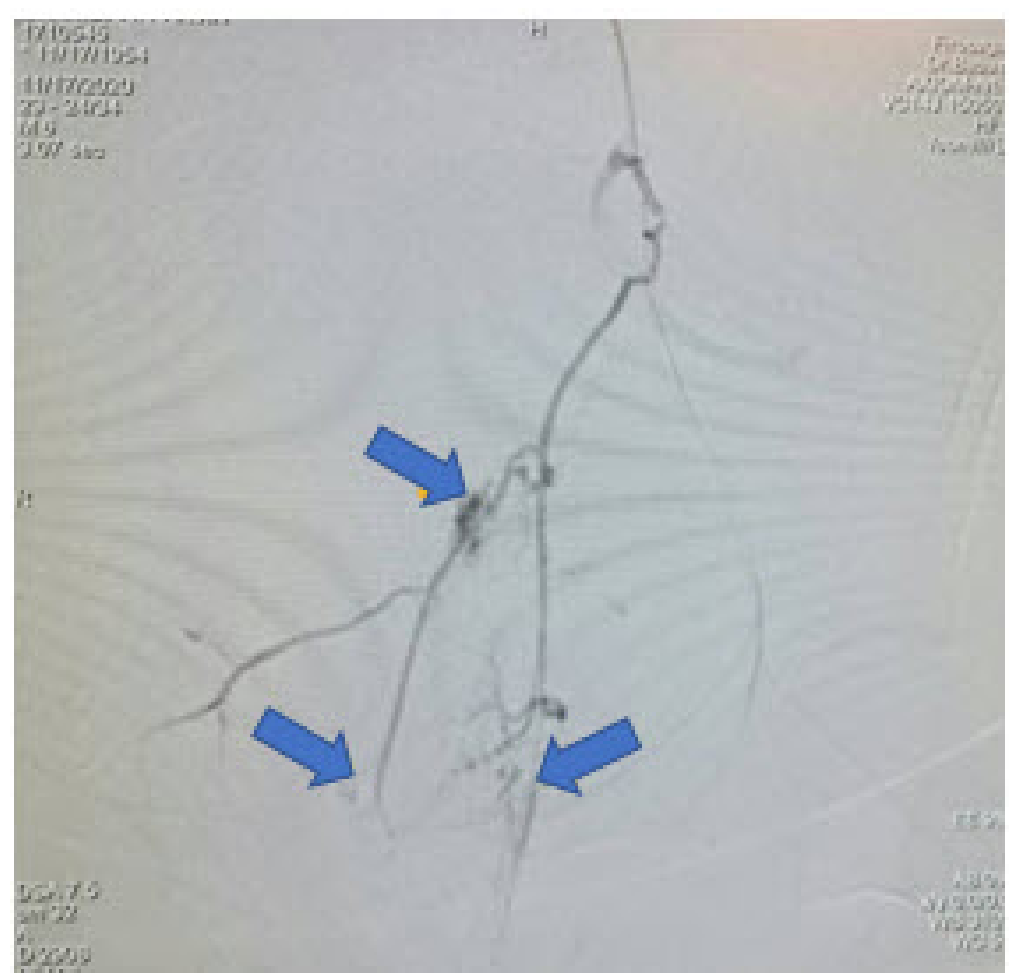

شكل r. آنزيوكرافى DSA شريان هاى للَنى، كانون هاى متعدد خونريزى كف لكن كه به صورت

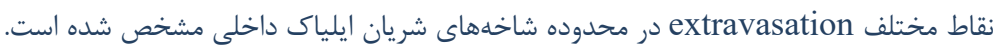

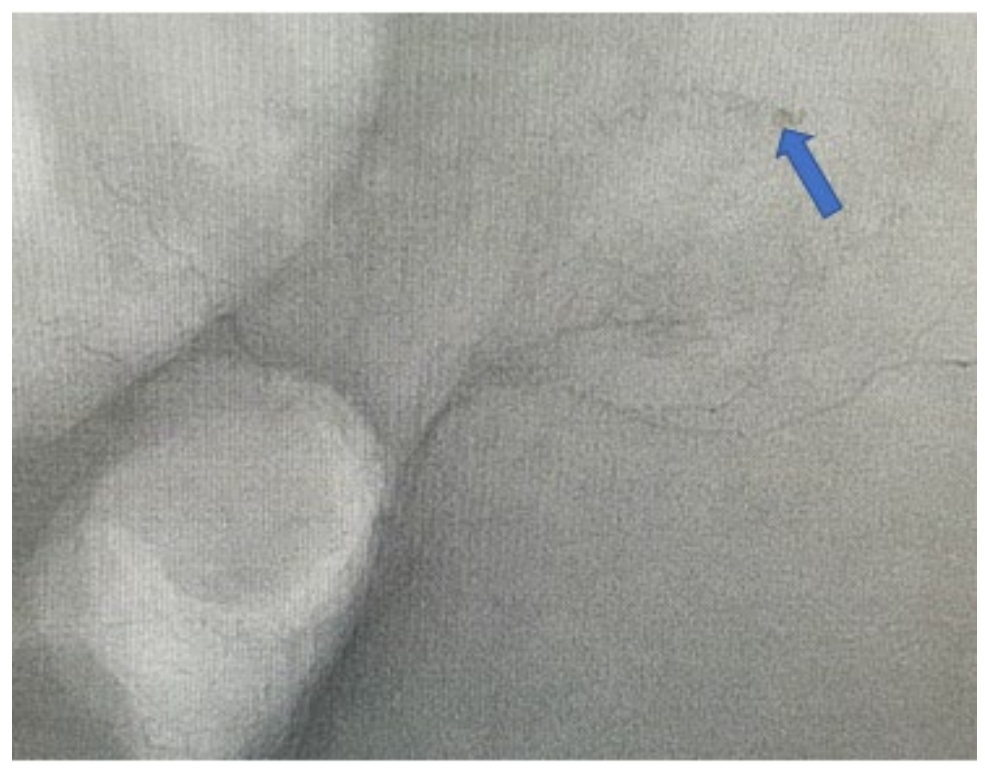

شكل r. آنزيوكرافى سلكتيو، تصوير Blush شريانى در محدوده خونرسانى شريان إييحاستريك تحتانى نشاندهنده محل خونريزى

خونريزى در اين بيماران به عوارض همورازيك ناشى از هيارين

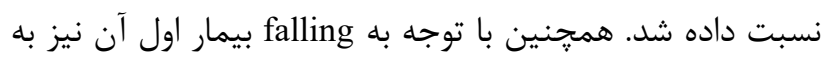

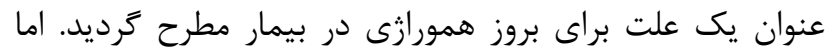

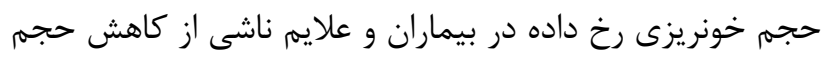

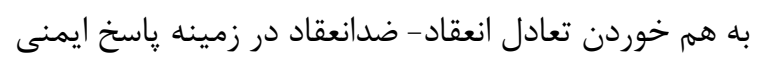

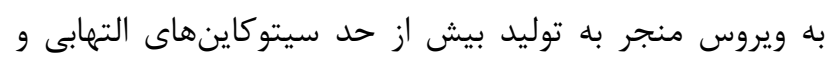

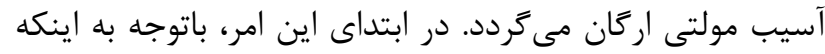

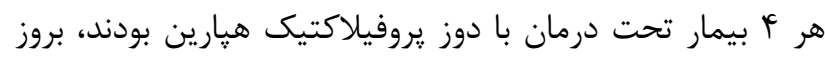


كوويد 19 و درمان مناسب آنها روشن سازد (Y |, س I). هم جنين

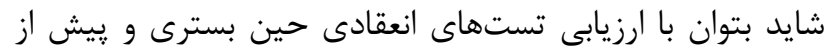

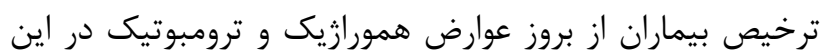

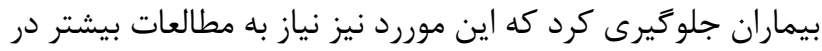
اين زمينه دارد. نتيجهليرى

اطلاعات و يافته ها در مورد اختلالات انعقادى كوويد 19 هم

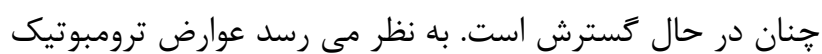
دربيماران كوويد 19 شايع مى باشد و نياز به تدوين و به اله روزرسانى

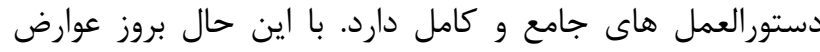

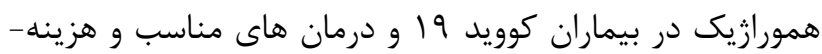
اثربخش در اين بيماران بايد مورد توجه باشد.

سياسگزارى

بدينوسيله از دانشعاه علوم يزشكى و خدمات بهداشتى

$$
\begin{aligned}
& \text { درمانى ايران تشكر مىشود. } \\
& \text { تعارض در منافع } \\
& \text { كزارش نشده است. } \\
& \text { منابع مالى } \\
& \text { ندارد. }
\end{aligned}
$$

\section{Referance}

1. Sun J, He W-T, Wang L, Lai A, Ji X, Zhai X, et al. COVID-19: epidemiology, evolution, and crossdisciplinary perspectives. Trends Mol Med. 2020;26(5):483-95.

[DOI:10.1016/j.molmed.2020.02.008] [PMID] [PMCID]

2. Danesh F, GhaviDel S, Piranfar V. Coronavirus: Discover the Structure of Global Knowledge, Hidden Patterns \& Emerging Events. J Adv Med Biomed Res. 2020;28(130):253-64. [DOI:10.30699/jambs.28.130.253]

3. Ekpunobi N, Markjonathan I, Olanrewaju O, Olanihun D. Idiosyncrasies of COVID-19; A Review. Iran J Med Microbiol. 2020;14(3):290-6. [DOI:10.30699/ijmm.14.3.290]

4. Parvizi P, Jalilian M, Parvizi H, Amiri S, Mohammad Doust H. The COVID-19 Pandemic: Data Analysis,
بروز يافته در آنها در بررسى متون با عوارض ناشى از دوز

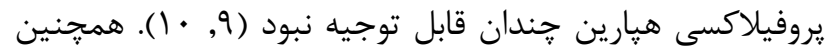

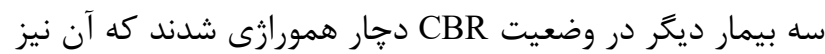
احتمال علت زمينهاى falling را براى همورازى كمتر محتمل دئل نمود. به تدريج توجه به بروز كواكولوياتى در بيماران مبتلا به كرونا

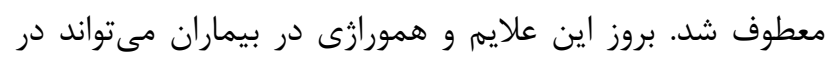

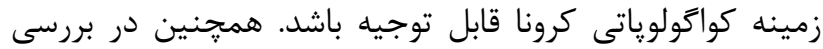

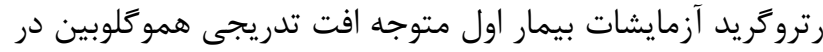

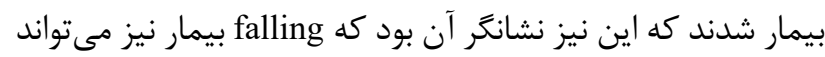

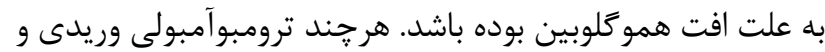
ترومبوز شريانى در كواكولوياتى ناشى از كوويد 19 شايعتر هستند،

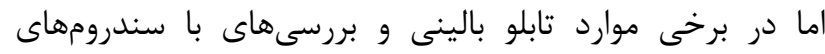

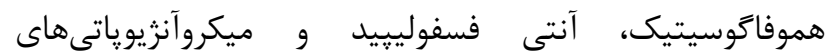
ترومبوتيك نيز هميوشانى دارد (1) (1). بهعلاوه، استفاده از هيارين يروفيلاكسى در بيماران كوويد 19 همجنان محل اختلاف نظر

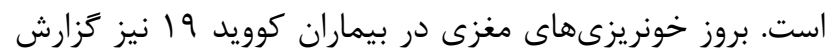

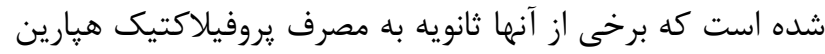

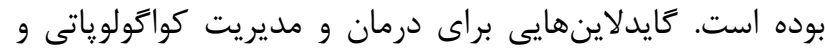

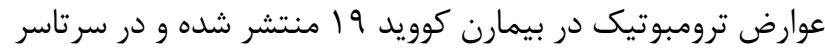

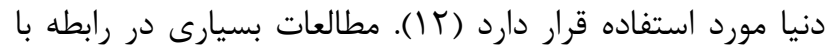

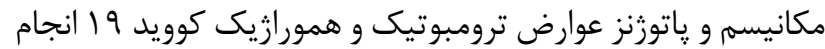

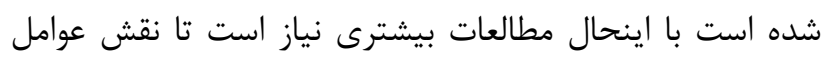

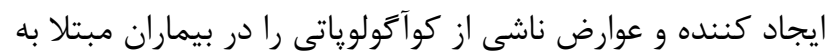

Impacts and Future Considerations. Iran $\mathrm{J}$ Med Microbiol. 2021;15(1):1-17. [DOI:10.30699/ijmm.15.1.1]

5. Hamming I, Timens W, Bulthuis M, Lely A, Navis Gv, van Goor HJTJoPAJotPSoGB, et al. Tissue distribution of ACE2 protein, the functional receptor for SARS coronavirus. A first step in understanding SARS pathogenesis. 2004;203(2):631-7. [DOI:10.1002/path.1570] [PMID] [PMCID]

6. Klok F, Kruip M, Van der Meer N, Arbous M, Gommers D, Kant K, et al. Incidence of thrombotic complications in critically ill ICU patients with COVID-19.

2020. [DOI:10.1016/j.thromres.2020.04.013] [PMCID]
[PMID] 
7. Azhdeh S, Mohammadi-Vajari M-A, Khaleghi M. Mesenteric Ischemia in a Case of COVID-19. Case Reports in Clinical Practice. 2020;5(Covid-19):1414.

8. Iba T, Levy JH, Levi M, Thachil J. Coagulopathy in COVID-19. J Thromb Haemost. 2020;18(9):2103-9. [DOI:10.1111/jth.14975] [PMID] [PMCID]

9. Al-Samkari H, Karp Leaf RS, Dzik WH, Carlson JC, Fogerty AE, Waheed A, et al. COVID-19 and coagulation: bleeding and thrombotic manifestations of SARS-CoV-2 infection. Blood, The Journal of the American Society of Hematology. 2020;136(4):489500. [DOI:10.1182/blood.2020006520] [ [PMCID]

10. Dogra S, Jain R, Cao M, Bilaloglu S, Zagzag D, Hochman S, et al. Hemorrhagic stroke and anticoagulation in COVID-19. J Stroke Cerebrovasc Dis. 2020;29(8):104984. [DOI:10.1016/j.jstrokecerebrovasdis.2020.104984] [PMID] [MCID]

11. Iba T, Levy JH, Connors JM, Warkentin TE, Thachil J, Levi M. The unique characteristics of COVID-19 coagulopathy. Critical Care. 2020;24(1):1-8. [DOI:10.1186/s13054-020-03077-0] [피] [PMCID]

12. Thachil J, Tang N, Gando S, Falanga A, Cattaneo M, Levi $\mathrm{M}$, et al. ISTH interim guidance on recognition and management of coagulopathy in COVID-19. J Thromb Haemost. 2020;18(5):1023-6. [DOI:10.1111/jth.14810] [PMID]

13. Becker RC. COVID-19 update: Covid-19-associated coagulopathy. J Thromb Haemost. 2020;50:54-67. [DOI:10.1007/s11239-020-02134-3] [PMID] [PMCID] 